\title{
Sleep quality is inversely related to body mass index among university students
}

\author{
(iD) Jun Wang ${ }^{1}$ \\ Yan Chen ${ }^{1}$ \\ (D) Yuelong Jin ${ }^{1}$ \\ (iD) Lijun Zhu ${ }^{1}$ \\ (iD) Yingshui Yao'
}

1. Department of epidemiology and biostatistics, School of public health, Wannan Medical College, Wuhu 241001, China.

\section{SUMMARY}

OBJECTIVE: The purpose of this study was to investigate the prevalence of overweight and obesity and its association with sleep quality in university students from the Anhui province in China.

METHODS: A cross-sectional study was conducted in China with 1328 participants. The prevalence of underweight and obesity in university students was estimated according to the reference working group on obesity in China. The sleep quality was evaluated using the standard PSQI (Pittsburgh Sleep Quality Index).

RESULTS: This study included 470 male and 858 female students from a university in Anhui; $4.4 \%$ of the females and $17.7 \%$ of the males were overweight or obese. The prevalence of obesity in males was significantly higher than in females, and the prevalence of obesity in higher years was greater than in other years ( $p<0.05)$. In general, the mean score for sleep quality was $4.91 \pm 2.67 ; 36.5 \%$ of male and $39.1 \%$ of female students had poor sleep quality (PSQI score $>5$ ). Among the seven components of sleep quality, sleep duration and the use of sleep medication showed significant differences between male and female students and different years ( $p<0.05)$. An obvious correlation was found between sleep quality and body mass index $(B M I)(p<0.000)$ in females who took hypnotic drugs.

CONCLUSION: This study suggests that the sleep quality offemales is probably associated with their BMI. College students are a special group of young adults whose cause of poor sleeping quality and BMI may be significant to study, so the health status of university students can be improved.

KEYWORDS: BMI; sleep quality; university students

\section{INTRODUCTION}

Overweight and obesity are rapidly becoming a major global public health problem ("globesity") $)^{1-3}$. Although the perception of obesity has improved, and the treatment of obesity has increased, global obesity rates are still on the rise ${ }^{4-6}$. A survey found that one- third of university students in Spain was either overweight or obese ${ }^{7}$. The relative prevalence of obesity in Asian populations is lower than in other parts of the world, according to the World Health Organization ${ }^{8}$. However, the prevalence of obesity is increas-

DATE OF SUBMISSION: 25-Jun-2018

DATE OF ACCEPTANCE: 10-Jul-2018

CORRESPONDING AUTHOR: Yingshui Yao

Wenchangxi road 22 - Wuhu - 241002 - China - Fax: +86-553-3932466, Tel: +86-553-3932466

E-mail: yingshuiyao@163.com 
ing in China. According to the Chinese National Survey, $23.2 \%$ of Chinese adults are overweight or obese. University students have a high level of knowledge, a great potential for development and are a creative group; their impact on the nation's future development is of far-reaching significance. Therefore, the influence of obesity on university students' physical and mental health should not be ignored.

University life brings many new and stressful challenges, self-responsibility, variable schedules, repeated deadlines, dormitory living, disorganized lifestyle, increased freedom, and social and academic obligations. In order to deal with these challenges, students voluntarily change their sleeping habits. Previous studies have found that $67 \%$ of students suffer from sleep disturbances and poor sleep quality ${ }^{9}$. Poor sleep quality significantly affects university students' ability to study and daily life, causes interpersonal tension, and may even cause other physiological disorders. Moreover, the relationship between sleep and obesity may vary across race and gender groups. Research on sleep is mainly undertaken in the West and focuses on the relationship between sleep duration and obesity. For instance, research shows that the relationship between sleep duration and obesity may form a J-shaped or U-shaped curve ${ }^{10-14}$. Data from Eastern countries are scarce, and there are insufficient data on university students ${ }^{15 ; 16}$. In order to understand the relationship between body mass indexes (BMI) and sleep quality in students, we conducted this cross-sectional study on university students in South Anhui (China).

\section{METHODS}

\section{Participants}

A random multistage cluster sampling method was used to select the study population from six universities in the southern Anhui region, China, from December 2014 to February 2015. We selected university students from different programs to represent college students and used a questionnaire survey in classes. Trained investigators administered the questionnaire survey to 1400 students and measured relevant indicators. Seventy-two participants were excluded because of missing information, and 1328 participants aged 19-23 years remained in the present analysis (470 males and 858 females). All participants agreed to provide their personal infor- mation regarding the purpose and the procedures of our study, and written informed consent was obtained.

\section{BMI}

Weight and height were self-reported by the students. The BMI was computed using a standard equation (BMI = weight in $\mathrm{kg} /$ height squared in meters), according to the Working Group on Obesity in China ${ }^{17}$. Body type was categorized as follows: underweight $(\mathrm{BMI}<18.5)$; normal $(18.5<\mathrm{BMI}<23.9)$; overweight $(24.0<\mathrm{BMI}<27.9)$; and obese $(\mathrm{BMI} \geq 28)$. The cutoff points for overweight and obesity were 24 and 28 , respectively.

\section{Sleep quality}

We used the Chinese version of the Pittsburgh Sleep Quality Index (PSQI), which has good reliability $^{18}$, to assess the sleep quality of college students over the previous month. The PSQI consists of 19 items that generate seven components: subjective sleep quality; sleep latency; sleep duration; habitual sleep efficiency; sleep disturbances; use of sleep medication; and daytime dysfunction. Each item is rated on a four-point scale ranging from "none" (zero) to "three times a week" (three). The sum of the scores for all items is the total PSQI score, with a total score range of 0 to 21 points. Higher global scores indicate worse sleep quality. The evaluation of sleep quality followed global recommended standards (score $\leq 5$ : good; score $>5$ : poor). In addition, we divided the PSQI into two more detailed classifications for further research.

\section{Statistical analyses}

All data were double entered into an EpiData3.1 database; SPSS16.0 software was used to analyze data on BMI and sleep quality among the university students. The chi-square test or Fisher's exact test was used for categorical variables, and one-way ANOVA was used for continuous variables. A twotailed P-value of $<0.05$ was considered significant for all tests.

\section{RESULTS}

Body type of university students

There were 1328 participants, 470 males (35.4\%) and 858 females (64.6\%); their age ranged from 19 to 23 years $($ mean $\pm \mathrm{SD}=19.50 \pm 1.33)$. The overall 
mean BMI was 20.63 ( $\mathrm{SD}=2.83$ ); male: mean $\pm \mathrm{SD}=$ $21.67 \pm 3.29$, female: mean $\pm \mathrm{SD}=20.06 \pm 2.37$. Among the university students, 249 (18.75\%) were underweight, 958 (72.14\%) were of normal weight, 91 (6.85\%) were overweight, and 30 (2.26\%) were obese. The two genders and different years had different prevalence of underweight, overweight and obesity, and the differences were statistically significant $(\mathrm{p}<0.05$; Table 1).

\section{Sleep quality of university students}

The mean score on the PSQI was 4.91 (SD=2.67), and no statistically significant differences were found for overall quality of sleep between male and female students, or among different years $(p=0.077)$. Among the seven dimensions of the PSQI score, a gender difference and a year difference existed for sleep duration and use of sleep medication $(p<0.05)$. In addition, the sleep disturbance score differed between male and female students, and there was a significant difference in the sleep latency score $(p<0.05)$ (Table 2).

The associations between sleep quality and BMI

On testing the correlation between the two kinds of classification of PSQI and overweight or obesity, we found that the PSQI 2 and BMI among females showed some correlation (Table3).

\section{DISCUSSION}

The mean BMI of the students included in the study was 20.63, which was lower than that of Chinese adults ${ }^{19}$. We also found that the prevalence of overweight and obesity in male students was higher than that in females. Moreover, the prevalence of underweight was obviously higher than the prevalence of obesity. Wronka et al. ${ }^{20}$ conducted a study on 1129 women in the south of Poland; they observed that the prevalence of underweight was higher than the prevalence of overweight and obesity, especially in students from high income families. Previous studies have also observed that gender is a contributing factor for the classification of $\mathrm{BMI}^{21,22}$. The two main explanations for this phenomenon are that university students have unhealthy eating behavior and inadequate nutrient intake ${ }^{23}$, and that females may have higher leptin concentrations than males ${ }^{21,22}$. In addition, we found that the prevalence of obesity among senior students was higher than in other years, and that the prevalence of obesity in first-year students was lower than in other years.

The proportion with poor quality of sleep was $36.5 \%$ for men and $39.1 \%$ for women; this result is lower than that found by Mesquita's research on sleep quality in Brazilian college students ${ }^{24}$. How-

TABLE 1 - BMI OF COLLEGE STUDENTS (PERCENTAGE)

\begin{tabular}{l|l|l|l|l|l|l|l} 
Variable & & Underweight & Normal & Overweight & Obesity & Total & $\chi^{2}$ \\
\hline gender & Male & $52(11.1)$ & $335(71.3)$ & $62(13.2)$ & $21(4.5)$ & 470 & 81.37 \\
\hline & Female & $197(23.0)$ & $623(72.6)$ & $29(3.4)$ & $9(1.0)$ & 858 & 0.00 \\
\hline & Freshmen & $149(21.4)$ & $492(70.7)$ & $46(6.6)$ & $9(1.3)$ & 696 & 19.38 \\
\hline & Sophomore & $55(14.7)$ & $276(73.8)$ & $29(7.8)$ & $14(3.7)$ & 374 & 0.02 \\
\hline & Juniors & $33(16.9)$ & $146(74.9)$ & $13(6.7)$ & $3(1.5)$ & 195 & \\
\hline
\end{tabular}

TABLE 2 - SLEEP QUALITY OF UNIVERSITY STUDENTS IN EACH COMPONENT (MEAN士S.D.)

\begin{tabular}{|c|c|c|c|c|c|c|c|c|}
\hline Item & $\begin{array}{l}\text { Subjective } \\
\text { sleep } \\
\text { quality }\end{array}$ & $\begin{array}{l}\text { Sleep } \\
\text { latency; }\end{array}$ & $\begin{array}{l}\text { Sleep dura- } \\
\text { tion }\end{array}$ & $\begin{array}{l}\text { Habitual sleep } \\
\text { efficiency }\end{array}$ & $\begin{array}{l}\text { Sleep distur- } \\
\text { bances }\end{array}$ & $\begin{array}{l}\text { Use of } \\
\text { sleep medi- } \\
\text { cation }\end{array}$ & $\begin{array}{l}\text { Daytime } \\
\text { dysfunction }\end{array}$ & PSQI score \\
\hline Male & $0.81 \pm 0.71$ & $0.61 \pm 0.88$ & $0.71 \pm 0.59$ & $0.20 \pm 0.60$ & $0.96 \pm 0.92$ & $0.23 \pm 0.58$ & $1.23 \pm 0.89$ & $4.74 \pm 2.76$ \\
\hline Female & $0.85 \pm 0.67$ & $0.71 \pm 0.90$ & $0.78 \pm 0.50$ & $0.16 \pm 0.48$ & $1.09 \pm 0.96$ & $0.10 \pm 0.38$ & $1.32 \pm 0.86$ & $4.99 \pm 2.61$ \\
\hline $\mathrm{t}$ & 1.28 & 3.82 & 4.76 & 1.89 & 5.72 & 25.78 & 3.34 & 2.64 \\
\hline$P$ & 0.258 & 0.051 & 0.029 & 0.170 & 0.017 & 0.000 & 0.068 & 0.104 \\
\hline Freshmen & $0.82 \pm 0.69$ & $0.63 \pm 0.87$ & $0.81 \pm 0.48$ & $0.16 \pm 0.48$ & $1.02 \pm 0.93$ & $0.11 \pm 0.41$ & $1.31 \pm 0.82$ & $4.86 \pm 2.60$ \\
\hline Sophomore & $0.84 \pm 0.67$ & $0.63 \pm 0.87$ & $0.74 \pm 0.56$ & $0.20 \pm 0.58$ & $1.01 \pm 1.02$ & $0.17 \pm 0.52$ & $1.31 \pm 0.92$ & $4.91 \pm 2.76$ \\
\hline Juniors & $0.96 \pm 0.70$ & $0.90 \pm 0.98$ & $0.65 \pm 0.60$ & $0.21 \pm 0.63$ & $1.12 \pm 0.86$ & $0.23 \pm 0.54$ & $1.25 \pm 0.95$ & $5.26 \pm 2.72$ \\
\hline Seniors & $0.81 \pm 0.64$ & $0.68 \pm 0.84$ & $0.44 \pm 0.50$ & $0.10 \pm 0.53$ & $1.16 \pm 0.95$ & $0.08 \pm 0.37$ & $1.03 \pm 0.82$ & $4.30 \pm 2.49$ \\
\hline $\mathrm{F}$ & 0.73 & 5.04 & 12.98 & 1.38 & 1.05 & 4.63 & 2.25 & 2.29 \\
\hline p & 0.536 & 0.002 & 0.000 & 0.248 & 0.371 & 0.003 & 0.081 & 0.077 \\
\hline
\end{tabular}


ever, the sleep quality of university students is generally poor, and comprehensive measures should be taken to improve the quality of sleep and promote college students' physical and mental health. Our study found that sleep quality was not associated with sex or year, which is consistent with previous studies ${ }^{9 ; 25}$ . Sleep quality was measured on seven dimensions. Sleep duration, sleep disturbance and medication use were associated with sex. Through the study of classification variables, sleep quality was found to be good in more male than female students.

After subdividing the low PSQI scores, we found that sleep quality in female students, but not in males, was associated with BMI; however, Mota and Vale ${ }^{26}$ reported that poor sleep quality was not associated with BMI. The seven dimensions of the sleep quality score were not associated with different BMI categories in males in our study, but the score relating to the use of sleep medication was associated with different BMI categories in females: obese females were significantly more likely to use such drugs than non-obese females. Female students may be more sensitive to problems with sleep quality and BMI. Furthermore, the use of different classifications on the PSQI can give different relationships between BMI and sleep quality, which suggests that different classifications of PSQI may influence the study of sleep quality and should be chosen carefully in future studies.

\section{Strengths and Limitations}

The strengths of our study include a large sample size, the use of well-trained interviewers and the valuable data pool. However, limitations to our study must also be considered when interpreting results. First, the sample size in different groups was small; for example, there was a small sample of senior students and more females were included than males, which may have affected the correlation found between sleep quality and BMI. Second, none of these findings demonstrated a causal relationship, due to the cross-sectional design of the study, and we did not investigate the correlation with the university programs and their relevance. Finally, we did not analyze the college students' eating habits or practice of physical exercise, which previous studies have found to be related to sleep and obesity ${ }^{27-29}$.

\section{CONCLUSION}

Our study shows that BMI and sleep quality of college students vary according to gender and year. After adjusting the classification of PSQI, we found that sleep quality differed between male and female students. By researching the different dimensions of the PSQI, we also found that the relationship between the BMI and sleep quality was important only in female students who took hypnotic drugs. College students are a special group, and therefore it is important to study their sleep quality, as well as the relationship between sleep quality and body type. In addition, the government and school-related departments concerned should place great importance on the mental and physical health of college students.

Author Contributions: Yingshui Yao and Yuelong Jin conceived and designed the experiments. LiJun Zhu and Yuelong Jin performed the experiments. Yan Chen analysed the data. Jun Wang wrote the paper.

TABLE 3 - COMPARISON OF SLEEP INDICATORS AMONG DIFFERENT BODYTYPES (MEAN \pm S.D.)

\begin{tabular}{|c|c|c|c|c|c|c|c|c|}
\hline & & $\begin{array}{l}\text { Sleep } \\
\text { quality }\end{array}$ & Sleep time & Sleep duration & $\begin{array}{l}\text { Sleep effi- } \\
\text { ciency }\end{array}$ & $\begin{array}{l}\text { Sleep distur- } \\
\text { bance }\end{array}$ & $\begin{array}{l}\text { Hypnotic } \\
\text { drugs }\end{array}$ & $\begin{array}{l}\text { Daytime } \\
\text { dysfunction }\end{array}$ \\
\hline \multirow[t]{4}{*}{ Male } & Underweight & $0.81 \pm 0.63$ & $0.63 \pm 0.86$ & $0.52 \pm 0.61$ & $0.11 \pm 0.47$ & $0.94 \pm 0.92$ & $0.33 \pm 0.68$ & $1.37 \pm 0.89$ \\
\hline & Normal & $0.83 \pm 0.72$ & $0.59 \pm 0.87$ & $0.73 \pm 0.58$ & $0.22 \pm 0.62$ & $0.93 \pm 0.93$ & $0.23 \pm 0.57$ & $1.21 \pm 0.88$ \\
\hline & Overweight & $0,74 \pm 0.72$ & $0.66 \pm 0.94$ & $0.71 \pm 0.61$ & $0.19 \pm 0.62$ & $1.03 \pm 0.89$ & $0.19 \pm 0.54$ & $1.29 \pm 0.96$ \\
\hline & Obesity & $0.76 \pm 0.62$ & $0.62 \pm 0.92$ & $0.71 \pm 0.56$ & $0.10 \pm 0.44$ & $1.10 \pm 0.04$ & $0.23 \pm 0.58$ & $1.14 \pm 0.79$ \\
\hline $\mathrm{F}$ & & 0.24 & 0.13 & 2.06 & 0.701 & 0.36 & 0.619 & 0.65 \\
\hline $\mathrm{P}$ & & 0.865 & 0.940 & 0.104 & 0.552 & 0.779 & 0.603 & 0.586 \\
\hline \multirow[t]{4}{*}{ Female } & Underweight & $0.90 \pm 0.74$ & $0.76 \pm 0.87$ & $0.82 \pm 0.51$ & $0.20 \pm 0.57$ & $1.16 \pm 1.00$ & $0.13 \pm 0.42$ & $1.28 \pm 0.81$ \\
\hline & Normal & $0.83 \pm 0.64$ & $0.69 \pm 0.91$ & $0.76 \pm 0.49$ & $0.15 \pm 0.46$ & $1.06 \pm 0.95$ & $0.08 \pm 0.36$ & $1.33 \pm 0.86$ \\
\hline & Overweight & $0.72 \pm 0.70$ & $0.66 \pm 0.81$ & $0.90 \pm 0.62$ & $0.14 \pm 0.35$ & $1.14 \pm 0.74$ & $0.07 \pm 0.26$ & $1.45 \pm 0.95$ \\
\hline & Obesity & $0.78 \pm 0.67$ & $0.78 \pm 0.97$ & $0.67 \pm 0.50$ & $0.00 \pm 0.00$ & $0.78 \pm 0.67$ & $0.66 \pm 1.00$ & $1.44 \pm 0.88$ \\
\hline $\mathrm{F}$ & & 1.90 & 0.31 & 1.452 & 1.00 & 0.88 & 7.71 & 0.41 \\
\hline$P$ & & 0.129 & 0.820 & 0.226 & 0.392 & 0.450 & 0.000 & 0.748 \\
\hline
\end{tabular}


Conflicts of Interest: The authors declare no conflict of interest. The sponsors had no role in the design of the study, the collection, analyses or interpretation of data, in the writing of the manuscript, and in the decision to publish the results.

\section{Acknowledgment}

This work was supported by the National Natural Science Foundation of China (Grant No. 81541071 and No. 81673266 ).

\section{RESUMO}

OBJETIVO: O objetivo do estudo era investigar a prevalência de sobrepeso e obesidade e sua relação com a qualidade do sono em estudantes universitários da província de Anhui, China.

METOdologiA: Um estudo transversal foi realizado na China com 1328 participantes. A prevalência de baixo peso e obesidade em estudantes universitários foi estimada com base nas referências do Grupo de Trabalho sobre Obesidade da China. A qualidade do sono foi avaliada utilizando o padrão PSQI (Pittsburgh Sleep Quality Index).

RESULTADOS: O estudo incluiu 470 homens e 858 mulheres, todos estudantes universitários de Anhui; 4,4\% das mulheres e 17,7\% dos homens foram classificados com sobrepeso ou obesidade. A prevalência da obesidade em homens foi significativamente maior do que em mulheres, e a prevalência da obesidade nos últimos anos foi maior do que em outras categorias $(P<0,05)$. Em geral, a pontuação média de qualidade do sono foi 4,91 $\pm 2,67 ; 36,5 \%$ dos homens e 39, 1\% das mulheres tiveram uma qualidade de sono ruim (PSQI > 5). Considerando os sete componentes da qualidade do sono, a duração do sono e o uso de medicação para dormir apresentaram diferenças significativas entre estudantes homens e mulheres de anos diferentes $(P<0,05)$. Uma clara correlação foi encontrada entre a qualidade do sono e o Índice de Massa corporal (IMC) $(P<0.0000)$ em mulheres que usavam drogas hipnóticas.

CONCLUSÃo: Este estudo sugere que a qualidade do sono das mulheres está provavelmente associada com o IMC. Os universitários são um grupo especial de jovens adultos, por isso é importante para estudar a causa da sua má qualidade do sono e sua relação com - IMC, para que seja possível melhorar a saúde dos estudantes universitários.

PALAVRAS - CHAVE: IMC, a qualidade do sono; estudantes universitários

\section{REFERENCES}

1. SERRA-MAIEM, L. and BAUTISTA-CASTANO, I. Relationship between bread and obesity. Br J Nutr 2015;113 Suppl 2: S29-35.

2. BROWN, T. SMITH, S. BHOPAL, R. KASIM, A. and SUMMERBELL, C. Diet and physical activity interventions to prevent or treat obesity in South Asian children and adults: a systematic review and meta-analysis. Int / Environ Res Public Health 2015;12: 566-94.

3. AGHA-ALINEJAD, H. FARZAD, B. SALARI, M. KAMJOO, S. HARBAUGH, B. L. and PEERI, M. Prevalence of overweight and obesity among Iranian preschoolers: Interrelationship with physical fitness. I Res Med Sci2015;20: 334-41.

4. ZWIAUER, K. F. Prevention and treatment of overweight and obesity in children and adolescents. Eur J Pediatr 2000;159 Suppl 1: S56-68.

5. NACKERS, L. M. DUBYAK, P. J. LU, X. ANTON, S. D. DUTTON, G. R. and PERRI, M. G. Group dynamics are associated with weight loss in the behavioral treatment of obesity. Obesity (Silver Spring) 2015;23: 1563-9.

6. LOPEZ-GARCIA, E. FAUBEL, R. LEON-MUNOZ, L. ZULUAGA, M. C. BANEGAS, J. R. and RODRIGUEZ-ARTALEJO, F. Sleep duration, general and abdominal obesity, and weight change among the older adult population of Spain. Am J Clin Nutr 2008;87: 310-6.

7. GONZALEZ SANDOVAL, C. E. DIAZ BURKE, Y. MENDIZABAL-RUIZ, A. P. MEDINA DIAZ, E. and MORALES, I. A. [Prevalence of obesity and altered lipid profile in university students]. Nutr Hosp 2014;29: 315-21.

8. ORGANIZATION., W. H. Global Database on Body Mass Index.

9. OMAR, A. and ET, A. Sleep Quality Among University Students: Evaluating the Impact of Smoking, Social Media Use, and Energy Drink Consumption on Sleep Quality and Anxiety. 2013;5.

10. TAHERI, S. LIN, L. AUSTIN, D. YOUNG, T. and MIGNOT, E. Short sleep duration is associated with reduced leptin, elevated ghrelin, and increased body mass index. PLoS Med 2004;1: e62.
11. PATEL, S. R. AYAS, N. T. MALHOTRA, M. R. WHITE, D. P. SCHERNHAMMER, E. S. SPEIZER, F. E., et al. A prospective study of sleep duration and mortality risk in women. Sleep 2004;27: 440-4.

12. KRIPKE, D. F. GARFINKEL, L. WINGARD, D. L. KLAUBER, M. R. and MARLER, M. R. Mortality associated with sleep duration and insomnia. Arch Gen Psychiatry 2002;59: 131-6.

13. GILDNER, T. E. LIEBERT, M. A. KOWAL, P. CHATTERII, S. and JOSH SNODGRASS, J. Sleep duration, sleep quality, and obesity risk among older adults from six middle-income countries: findings from the study on global AGEing and adult health (SAGE). Am / Hum Biol 2014;26: 803-12.

14. BAE, D. WICKRAMA, K. A. and O'NEAL, C. W. Social consequences of early socioeconomic adversity and youth BMI trajectories: gender and race/ethnicity differences. J Adolesc 2014;37: 883-92.

15. XIANG, Y. T. MA, X. LU, J. Y. CAI, Z. J. LI, S. R. XIANG, Y. Q., et al. Relationships of sleep duration with sleep disturbances, basic socio-demographic factors, and BMI in Chinese people. Sleep Med 2009;10: 1085-9.

16. TU, X. CAI, H. GAO, Y. T. WU, X. II, B. T. YANG, G., et al. Sleep duration and its correlates in middle-aged and elderly Chinese women: the Shanghai Women's Health Study. Sleep Med 2012;13: 1138-45.

17. BEI-FAN, Z. Predictive values of body mass index and waist circumference for risk factors of certain related diseases in Chinese adults: study on optimal cut-off points of body mass index and waist circumference in Chinese adults. Asia Pac / Clin Nutr 2002;11: 685-9.

18. TSAI, P. S. WANG, S. Y. WANG, M. Y. SU, C. T. YANG, T. T. HUANG, C. I., et al. Psychometric evaluation of the Chinese version of the Pittsburgh Sleep Quality Index (CPSQI) in primary insomnia and control subjects. Qual Life Res 2005;14: 1943-52.

19. SHANKAR, B. Obesity in China: the differential impacts of covariates along the BMI distribution. Obesity (Silver Spring) 2010;18: 1660-6. 
20. WRONKA, I. SULIGA, E. and PAWLINSKA-CHMARA, R. Socioeconomic determinants of underweight and overweight in female Polish students in 2009. Anthropol Anz 2012;69: 85-96.

21. FALORNI, A. BINI, V. MOLINARI, D. PAPI, F. CELI, F. DI STEFANO, G., et al. Leptin serum levels in normal weight and obese children and adolescents: relationship with age, sex, pubertal development, body mass index and insulin. Int / Obes Relat Metab Disord 1997;21: 881-90.

22. AL-HARITHY, R. N. Relationship of leptin concentration to gender, body mass index and age in Saudi adults. Saudi Med I 2004;25: 1086-90.

23. GAN, W. Y. MOHD, N. M. ZALILAH, M. S. and HAZIZI, A. S. Differences in eating behaviours, dietary intake and body weight status between male and female Malaysian University students. Malays / Nutr 2011;17: 213-28.

24. MESQUITA, G. and REIMAO, R. Quality of sleep among university students: effects of nighttime computer and television use. Arq Neuropsiquiatr 2010;68: 720-5.
25. TSAI, L. L. and LI, S. P. Sleep patterns in college students: gender and grade differences. / Psychosom Res 2004;56: 231-7.

26. MOTA, J. and VALE, S. Associations between sleep quality with cardiorespiratory fitness and BMI among adolescent girls. Am / Hum Biol 2010;22: 473-5.

27. WANG, R. LIU, D. WANG, X. XIAO, W. WU, N. GAO, B., et al. The effect of 'sleep high and train low' on weight loss in overweight Chinese adolescents: study protocol for a randomized controlled trial. Trials 2014;15: 250.

28. PEUHKURI, K. SIHVOLA, N. and KORPELA, R. Diet promotes sleep duration and quality. Nutr Res 2012;32: 309-19.

29. NETZER, N. C. CHYTRA, R. and KUPPER, T. Low intense physical exercise in normobaric hypoxia leads to more weight loss in obese people than low intense physical exercise in normobaric sham hypoxia. Sleep Breath 2008;12: 129-34. 